\title{
Creativity Abilities of Seventh Grade Pupils in Slovenian Elementary Schools
}

Jerneja Herzog*

jerneja.herzog@um.si
UDK/UDC: UDK: 373.3(497.4):159.954

159.954:373.3(497.4)

Izvorni znanstveni rad / Original scientific paper

Primljeno: 31. srpnja 2017. / Received: July 31, 2017.

Prihvaćeno: 17. rujna 2017. / Accepted: September 17, 2017.

In the paper we present the findings of the empirical research study whose purpose was to monitor creativity abilities of seventh grade pupils in Slovenian elementary schools. More concretely, we monitored the levels of artistic-creative and artistic-formative development. The research sample consisted of 247 seventh graders in various elementary schools. We examined creativity abilities from the perspective of differences between the two genders. The results of the study showed at the level of artistic-formative development girls dominate, while no statistically significant differences were found in artistic-creative development.

Key words: artistic creative development of pupils; artistic formative development of children; creativity; teaching arts.

\footnotetext{
* Jerneja Herzog, PhD, Assist. Prof., Faculty of Education, University of Maribor, Koroška cesta 160, SI-2000 Maribor, Slovenia.
} 


\section{Introduction}

Dinkelmann notes in the framework of school opportunities for promoting artistic creativity are manifested in some particularities, as the latter is, as a rule, implemented in acting and in thinking. ${ }^{1}$ It can start from the examination of artistic materials or from free associative thinking games. There are various definitions of monitoring creativity. Some authors define the concept of creativity as »a process, a product; likewise, however, it can be linked to the personality or any other characteristic of person's environment. «

»Based on methodological premises, dealing with creativity American researchers distinguish between four aspects denoted by four P's: the press (environment), the personality, the process, and the product. $\ll^{3}$

Müller Braunschweig perceives creativity as something linked to the product, growth, and produced with new views. ${ }^{4}$ Holm Hadulla refers to the-to a large extent unanimous-opinion of researchers of creativity, which has its origins in the personality, saying courage, preparedness and the joy for nonconformism, as well as idiosyncrasy are typical characteristics of creative people. ${ }^{5}$ Pečjak believes the concept of creativity can be defined in a variety of ways, the problem, however, is none of them is perfectly suitable or sufficient. ${ }^{6}$ Also interesting is the understanding of Jurman, who says creativity is something more, »it is one's existential function, defining his or her purpose of life and existence. $\ll^{7}$

In visual arts creativity could be defined in the same way as artistic creativity in general »however, specific visual elements, hence the means of visual expression, must be added. $\aleph^{8}$ Ehrenzweig says analysis of the works of painters and of arts students has allowed him to study three phases of creativity he considers important. These are feedback in the introspection of artistic substructures, the break of modern art and the solutions of modern art. They feel

\footnotetext{
${ }^{1}$ Kai DINKELMANN, Kreativitätsförderung im Kunstunterricht, München, Herbert Utz Verlag, 2008, 13.

2 Paul Ellis TORRANCE, Kreativnost, Pedagogija - časopis saveza pedagoških društava Jugoslavije, 17 (1981) 1-2, 69-87, 70.

3 Anton TRSTENJAK, Psihologija ustvarjalnosti, Ljubljana, Slovenska matica, 1981, 535.

${ }^{4}$ Hans MÜLLER BRAUNSCHWEIG, Aspekte einer psychoanalytischen Kreativitätstheorie, in: Hartmut Kraft (ed.), Psychoanalyse, Kunst und Kreativität. Die Entwicklung der analytischen Kunstpsychologie seit Freud, Berlin, Medizinisch-wissenschaftliche Verlagsgesellschaft, ${ }^{3} 2007$, 87-105.

${ }^{5}$ Rainer M. HOLM HADULLA, Kreativität. Konzept und Lebensstil, Göttingen, Vandenhoeck \& Ruprecht, 2007.

${ }^{6}$ Vid PEČJAK, Misliti, delati, živeti ustvarjalno, Ljubljana, Državna založba Slovenije, 1987.

7 Benjamin JURMAN, Inteligentnost, ustvarjalnost, nadarjenost, Ljubljana, Center for Pshychology, 2004, 190.

${ }^{8}$ Matjaž DUH, Vrednotenje kot didaktični problem pri likovni vzgoji, Maribor, Pedagoška fakulteta, 2004.
} 
that they are developing only interacting with one another. ${ }^{9}$ Schuster believes artistic creativity is less the state of mind of the artist; it manifests rather as proximal innovation in the area of artistic depiction. A work of visual arts is the product of a creative process; it has multiple meanings and is multi-layered. The latter is reflected in the complexity of the emergence of an artwork..$^{10}$

»In arts education solving problems primarily refers to the set tasks. The task should be based on a genuine artistic-formation problem and ought to require independent interpretation ${ }^{11}$

In the research that measure artistic creativity through creative product ${ }^{12}$, six factors of artistic creativity are generally monitored. The factors resulting from divergent production are originality, flexibility, fluentness, and elaboration; while the factors sensitivity for visual arts problems and redefinition result from cognition. These are the factors that stimulate artistic creativity, because the component is dominant in them, while simultaneously they also contain elements that make creativity possible. ${ }^{13}$

When observing works of art, such as drawings, we are aware of the differences in the age development the latter indicate.

»In primary school education, the subject of visual arts enables students' permanent creative expression. It introduces them to perception and reception, i.e. evaluation of artwork «. ${ }^{14}$

Knowing the development of the child and of artistic features helps us understand his artistic expression. We are thus able to recognise and to monitor his progress or his lagging behind in artistic development.

${ }^{9}$ Anton EHRENZWEIG, Die drei Phasen der Kreativität (EA 1967/1974), in: Hartmut Kraft (ed.), Psychoanalyse, Kunst und Kreativität. Die Entwicklung der analytischen Kunstpsychologie seit Freud, Berlin, Medizinisch-wissenschaftliche Verlagsgesellschaft, 2007, 75-87.

${ }^{10}$ Martin SCHUSTER, Kunstpsychologie. Kreativität - Bildkommunikation - Schönheit, Baltmannsweiler, Schneider Verlag, 2000.

${ }^{11}$ Kai DINKELMANN, Kreativitätsförderung im Kunstunterricht, München, Herbert Utz Verlag, 2008, 15; www.utzverlag.de/assets/pdf/40754les.pdf (31.07.2017).

${ }^{12}$ Matjaž DUH, Vrednotenje kot didaktični problem pri likovni vzgoji, Maribor, Pedagoška fakulteta, 2004; Bogomil KARLAVARIS, Metodika likovnog odgoja 1, Rijeka, Hofbauer, 1991.

${ }^{13}$ Matjaž DUH, Vrednotenje kot didaktični problem pri likovni vzgoji, Maribor, Pedagoška fakulteta, 2004.

${ }^{14}$ Matjaž DUH, Jerneja HERZOG, Miroslav HUZJAK, Popularity of Art Motifs among FourthGrade Primary School Students in Slovenia and Croatia, The New Educational Review, 45 (2016) 1, 92-103. 


\section{Problem and Focus of Research}

The purpose of the research is to detect any existing differences between the genders in monitoring the creative and formational level of seventh graders in Slovenian elementary schools. The aim of the research is analysis of artistic skills. The artistic-creative and artistic-formational levels consist of several factors; we therefore monitored the results according to each individual factor and according to the overall level. With the obtained results we answered the research questions presented below (Table 1).

Table 1. Research questions according to gender

\begin{tabular}{|l|l|}
\hline $\begin{array}{l}\text { Factors of Creative Development } \\
\text { Is there a statistically significant difference between the genders in the: }\end{array}$ \\
\hline$R Q 1_{S}$ & overall level of creative process? \\
\hline$R Q 1_{S 1}$ & factor sensitivity for visual arts problems? \\
\hline$R Q 1_{S 2}$ & factor elaboration? \\
\hline$R Q 1_{S 3}$ & factor flexibility? \\
\hline$R Q 1_{S 4}$ & factor fluentness? \\
\hline$R Q 1_{S 5}$ & factor originality? \\
\hline$R Q 1_{S 6}$ & factor redefinition? \\
\hline Factors of Formational Development \\
\hline$R Q_{2 S}$ & overall level of formational development? \\
\hline$R Q_{2 S 1}$ & factor propagation of artistic elements? \\
\hline $\mathrm{RQ}_{2 S 2}$ & factor relations between artistic elements? \\
\hline $\mathrm{RQ}_{2 S 3}$ & factor composition? \\
\hline
\end{tabular}

\section{Methodology of Research}

\subsection{General Background of Research}

We applied the quantitative methodology with causal non-experimental method in educational empiric research, and in the qualitative part the descriptive and comparative methods. In determining differences we used the $t$-test.

\subsection{Sample of Research}

The research simple random sample consisted of 247 pupils of the seventh grade, of these 126 girls and 121 boys. Urban and suburban schools participated in the survey. 


\subsection{Instrument and Procedures}

For testing creativity and artistic expression the test was applied that with the study of the literature of existing research ${ }^{15}$ proved to be reliable, valid and sensitive for measuring artistic expression and abilities of 3 to 18 years old children. The measured criteria are optic-thematic (intellectual), creative, and formational development. With the support of a special rating scale, taken from previous research carried out by art educator Duh, ${ }^{16}$ we based on the child's test drawing. The purpose of the test drawing is measuring artistic expression through the motif Alien visiting me.

\subsection{Data Analysis}

The data were processed with the SPSS. We acquired results, which show the arithmetic mean $(\bar{x})$, standard deviation $(\mathrm{s})$, the test of the equality of variance and the test of the difference from the arithmetic mean.

\section{Results of Research}

In the table below the results of the artistic-creative level are presented by gender (Table 2), followed by interpretation.

Table 2. Outcomes of the t-test and F-test of results in relation to the gender of pupils at the overall level of creative development.

\begin{tabular}{|c|c|c|c|c|c|c|c|}
\hline \multirow{4}{*}{ Creative level } & \multirow{2}{*}{ G } & \multirow{2}{*}{$\bar{x}$} & \multirow{2}{*}{$\mathrm{s}$} & \multicolumn{2}{|c|}{ F test } & \multicolumn{2}{|c|}{ t-test } \\
\hline & & & & $\mathrm{F}$ & P & $\mathrm{t}$ & $\mathrm{P}$ \\
\hline & M & 3.0298 & 0.67078 & & & & \\
\hline & $\mathrm{F}$ & 3.0662 & 0.57344 & 3.356 & 0.068 & -0.461 & 0.646 \\
\hline
\end{tabular}

The analysis of the results (Table 2) of the overall level of art creative development shows there are no statistically significant differences in relation to gender $(\mathrm{P}=0.646)$. We can answer the question ( $\left.R Q 1_{\mathrm{s}}\right)$ and confirm in the overall level of artistic creativity there are no statistically significant differences between boys and girls.

\footnotetext{
${ }^{15}$ Matjaž DUH, Kompjutor u razvoju likovne kreativnosti kod učenika osnovne škole, magistarski rad, Rijeka, Pedagoški fakultet, 1996; Matjaž DUH, Likovna ustvarjalnost z računalniškimi orodji v slovenski snovni šoli, Sodobna pedagogika, 48 (1997) 9-10, 509-526.

${ }^{16}$ Matjaž DUH, Kompjutor u razvoju likovne kreativnosti kod učenika osnovne škole, magistarski rad, Rijeka, Pedagoški fakultet, 1996.
} 
Table 3. Outcomes of the t-test and F-test of results in relation to the gender of pupils in the factor sensitivity for artistic problems.

\begin{tabular}{|c|c|c|c|c|c|c|c|}
\hline \multirow{2}{*}{$\begin{array}{l}\text { Sensitivity for artistic } \\
\text { problems }\end{array}$} & \multirow{2}{*}{ G } & \multirow{2}{*}{$\bar{x}$} & \multirow{2}{*}{$\mathrm{s}$} & \multicolumn{2}{|c|}{ F test } & \multicolumn{2}{|c|}{ t-test } \\
\hline & & & & $\mathrm{F}$ & $\mathrm{P}$ & $t$ & $\mathrm{P}$ \\
\hline \multirow{2}{*}{ Sensibility } & $M$ & 2.1451 & 0.69104 & \multirow{2}{*}{0.653} & \multirow{2}{*}{0.420} & \multirow{2}{*}{-3.654} & \multirow{2}{*}{0.000} \\
\hline & $\mathrm{F}$ & 2.4452 & 0.60075 & & & & \\
\hline \multirow{2}{*}{$\begin{array}{l}\text { Recognition of artistic } \\
\text { problems on the motif }\end{array}$} & M & 2.5314 & 0.58701 & \multirow{2}{*}{0.701} & \multirow{2}{*}{0.403} & \multirow{2}{*}{-0.690} & \multirow{2}{*}{0.491} \\
\hline & $\mathrm{F}$ & 2.7230 & 0.63069 & & & & \\
\hline
\end{tabular}

The results in the factor sensibility (Table 3 ) shows a statistically significant difference between the genders $(\mathrm{P}=0.0000)$, which is in favour of girls, while in the factor recognition of artistic problems on the motif we noticed no statistically significant differences between girls and boys $(\mathrm{P}=0.491)$. We can answer the question (RQ $1_{S 1}$ ). We present the finding in the answer that in experiencing artistic problems (sensibility) girls perform better, while there are no differences between the genders in recognising artistic problems on the motif.

Table 4. Outcomes of the t-test and F-test of results in relation to the gender of pupils in the factor of creativity elaboration.

\begin{tabular}{|c|c|c|c|c|c|c|c|}
\hline \multirow{2}{*}{ Elaboration } & \multirow{2}{*}{ G } & \multirow[b]{2}{*}{$\bar{x}$} & \multirow{2}{*}{$\mathrm{s}$} & \multicolumn{2}{|c|}{$\mathrm{F}$ test } & \multicolumn{2}{|c|}{ t-test } \\
\hline & & & & $\mathrm{F}$ & $\mathrm{P}$ & $\mathrm{t}$ & $\mathrm{P}$ \\
\hline \multirow{2}{*}{$\begin{array}{l}\text { Conceptual and mental } \\
\text { elaboration }\end{array}$} & M & 1.8475 & 0.93058 & \multirow{2}{*}{1.151} & \multirow{2}{*}{0.284} & \multirow{2}{*}{-2.828} & \multirow{2}{*}{0.005} \\
\hline & $\mathrm{F}$ & 2.1746 & 0.89093 & & & & \\
\hline \multirow{2}{*}{$\begin{array}{l}\text { Aesthetic organisation } \\
\text { of expression }\end{array}$} & M & 2.2156 & 0.69354 & \multirow{2}{*}{2.020} & \multirow{2}{*}{0.157} & \multirow{2}{*}{-2.331} & \multirow{2}{*}{0.021} \\
\hline & $\mathrm{F}$ & 2.4103 & 0.62120 & & & & \\
\hline
\end{tabular}

A statistically significant difference between the genders (Table 4) shows in the conceptual and mental elaboration (P.0.005) and in the aesthetic organisation of expression $(\mathrm{P}=0.021)$. Both results are in favour of girls.

The achieved results answer the question (RQ $1_{\mathrm{S} 2}$ ) whether in elaboration there are differences in relation to gender. It was found girls achieved better results than boys in conceptual and mental elaboration of expression, in the preparation of creative process as well as in the aesthetic organisation of expression, where they were better able to harmonise the idea and the material than boys and to observe the formational rules in artistic planning. 
Table 5. Outcomes of the t-test and F-test of results in relation to the gender of pupils in the factor flexibility.

\begin{tabular}{|c|c|c|c|c|c|c|c|}
\hline \multirow{2}{*}{ Flexibility } & \multirow{2}{*}{ G } & \multirow{2}{*}{$\bar{x}$} & \multirow{2}{*}{$\mathrm{s}$} & \multicolumn{2}{|c|}{$F$ test } & \multicolumn{2}{|c|}{$\mathrm{t}$-test } \\
\hline & & & & $\mathrm{F}$ & P & $\mathrm{t}$ & $\mathrm{P}$ \\
\hline \multirow{2}{*}{ Discovering new ways } & M & 2.4656 & 0.64804 & \multirow{2}{*}{0.092} & \multirow{2}{*}{0.762} & \multirow{2}{*}{-0.647} & \multirow{2}{*}{0.518} \\
\hline & $\mathrm{F}$ & 2.5190 & 0.65394 & & & & \\
\hline \multirow{2}{*}{$\begin{array}{l}\text { Flexibility of adaptation } \\
\text { to means of expression }\end{array}$} & M & 2.0336 & 0.55753 & \multirow{2}{*}{0.531} & \multirow{2}{*}{0.467} & \multirow{2}{*}{-1.938} & \multirow{2}{*}{0.054} \\
\hline & $\mathrm{F}$ & 2.1651 & 0.51058 & & & & \\
\hline
\end{tabular}

The achieved results in discovering new ways in the search of artistic solutions (Table 5) do not indicate a statistically significant difference between the genders $(\mathrm{P}=0.518)$, while nevertheless in the flexible adaptation to means of expression a tendency of difference is expressed $(\mathrm{P}=0.054)$ in favour of girls. We can answer the question (RQ 1S3). In flexible adaptation to means of expression girls, who were better able to make use of the felt-tip pen, perform better, while in discovering new ways there are no differences between the genders.

Table 6. Outcomes of the t-test and F-test of results in relation to the gender of pupils in the factor artistic fluentness.

\begin{tabular}{|c|c|c|c|c|c|c|c|c|}
\hline \multirow{2}{*}{ Artistic fluentness } & \multirow{2}{*}{ G } & \multirow{2}{*}{$\mathrm{n}$} & \multirow{2}{*}{$\bar{x}$} & \multirow{2}{*}{$\mathrm{S}$} & \multicolumn{2}{|c|}{ F test } & \multicolumn{2}{|c|}{ t-test } \\
\hline & & & & & $\mathrm{F}$ & $\mathrm{P}$ & $\mathrm{t}$ & $\mathrm{P}$ \\
\hline \multirow{2}{*}{$\begin{array}{l}\text { Fluentness of artistic } \\
\text { ideas }\end{array}$} & M & 121 & 2.4033 & 0.59027 & \multirow{2}{*}{2.298} & \multirow{2}{*}{0.131} & \multirow{2}{*}{0.559} & \multirow{2}{*}{0.576} \\
\hline & $\mathrm{F}$ & 126 & 2.3627 & 0.55190 & & & & \\
\hline \multirow{2}{*}{$\begin{array}{l}\text { Motor skills in the } \\
\text { realisation of the idea }\end{array}$} & $M$ & 121 & 2.2016 & 0.66457 & \multirow{2}{*}{0.460} & \multirow{2}{*}{0.498} & \multirow{2}{*}{-2.273} & \multirow{2}{*}{0.024} \\
\hline & $\mathrm{F}$ & 126 & 2.3889 & 0.63299 & & & & \\
\hline
\end{tabular}

The results (Table 6) shows in the fluentness of artistic ideas there is no statistically significant difference $(\mathrm{P}=0.576)$, it is perceived, however, in the motor skills in the realisation of artistic ideas $(\mathrm{P}=0.024)$, where girls achieved better results. With the achieved results we can answer the question (RQ $1_{S 4}$ ). Thus the results of the research do not indicate a difference between the genders. We have detected a difference in favour of girls in the realisation of the idea. The result can be understood as a consequence of focussing on the final product, where in artistic creation the idea set at the beginning is pursued. 
Table 7. Outcomes of the t-test and F-test of results in relation to the gender of pupils in the factor originality.

\begin{tabular}{|c|c|c|c|c|c|c|c|}
\hline \multirow{2}{*}{ Artistic originality } & \multirow{2}{*}{ G } & \multirow[b]{2}{*}{$\bar{x}$} & \multirow{2}{*}{$\mathrm{s}$} & \multicolumn{2}{|c|}{ F test } & \multicolumn{2}{|c|}{ t-test } \\
\hline & & & & $\mathrm{F}$ & $\mathrm{P}$ & $\mathrm{t}$ & $\mathrm{P}$ \\
\hline \multirow{2}{*}{$\begin{array}{l}\text { Artistic originality as } \\
\text { individual sensibility }\end{array}$} & $M$ & 2.6270 & 0.69817 & \multirow{2}{*}{4.676} & \multirow{2}{*}{0.031} & \multirow{2}{*}{2.402} & \multirow{2}{*}{0.017} \\
\hline & $\mathrm{F}$ & 2.4310 & 0.58426 & & & & \\
\hline \multirow{2}{*}{$\begin{array}{l}\text { Originality in the sense } \\
\text { of observation }\end{array}$} & $M$ & 2.0295 & 0.53655 & \multirow{2}{*}{3.176} & \multirow{2}{*}{0.076} & \multirow{2}{*}{2.621} & \multirow{2}{*}{0.009} \\
\hline & $\mathrm{F}$ & 1.8683 & 0.42777 & & & & \\
\hline
\end{tabular}

The results in the table (Table 7) show statistically in artistic originality significant difference is indicated between the genders $(\mathrm{P}=0.017)$ in favour of boys. Likewise, we perceive a statistically significant difference in originality in the sense of observation $(\mathrm{P}=0.017)$, also in favour of boys. In both aspects of artistic originality boys achieved higher results than girls. The result can be attributed to greater playfulness in artistic creation and to searching for unusual solutions the test drawing makes possible. We can answer the question RQ $1_{S 5}$, we can answer that there are statistically significant differences in favour of boys.

Table 8. Outcomes of the t-test and F-test of results in relation to the gender of pupils in the factor artistic redefinition.

\begin{tabular}{|c|c|c|c|c|c|c|c|}
\hline \multirow{2}{*}{ Artistic redefinition } & \multirow{2}{*}{ G } & \multirow{2}{*}{$\bar{x}$} & \multirow{2}{*}{$\mathrm{s}$} & \multicolumn{2}{|c|}{ F test } & \multicolumn{2}{|c|}{ t-test } \\
\hline & & & & $\mathrm{F}$ & $\mathrm{P}$ & $\mathrm{t}$ & $\mathrm{P}$ \\
\hline \multirow{2}{*}{ Sensitive observation } & M & 2.0361 & 0.42525 & \multirow{2}{*}{1.717} & \multirow{2}{*}{0.191} & \multirow{2}{*}{2.582} & \multirow{2}{*}{0.010} \\
\hline & $\mathrm{F}$ & 1.9063 & 0.36458 & & & & \\
\hline \multirow{2}{*}{$\begin{array}{l}\text { Process of successful } \\
\text { artistic transposition }\end{array}$} & M & 1.8648 & 0.44498 & \multirow{2}{*}{4.915} & \multirow{2}{*}{0.028} & \multirow{2}{*}{3.248} & \multirow{2}{*}{0.001} \\
\hline & $\mathrm{F}$ & 1.6929 & 0.38744 & & & & \\
\hline
\end{tabular}

With the results we have determined (Table 8 ) a statistically significant difference $(\mathrm{P}=0.010)$ in sensitive observation in favour of boys. Likewise we have detected a statistically significant difference in favour of boys $(\mathrm{P}=0.001)$ in the process of artistic transposition. We can answer the question (RQ $\left.1_{\mathrm{S} 6}\right)$. We can answer that there are differences in the results that indicate in transforming; in creating new meanings of objects boys perform better than girls. We can understand the result as a consequence of greater desire for experimentation in boys compared to that of girls. In artistic creation they are not necessarily focussed on the final appearance of the product; in the process of creation itself they rather adapt it both to artistic means of expression and to artistic techniques and materials. 
Table 9. Outcomes of the t-test and F-test of results in relation to the gender of pupils in overall level of artistic-formational development.

\begin{tabular}{|c|c|c|c|c|c|c|c|}
\hline \multirow{3}{*}{ Formational level } & \multirow{2}{*}{ G } & \multirow[b]{2}{*}{$\bar{x}$} & \multirow{2}{*}{$\mathrm{S}$} & \multicolumn{2}{|c|}{ F test } & \multicolumn{2}{|c|}{ t-test } \\
\hline & & & & $\mathrm{F}$ & $\mathrm{P}$ & $\mathrm{t}$ & $\mathrm{P}$ \\
\hline & M & 2.6314 & 0.88337 & & & & \\
\hline & $\mathrm{F}$ & 3.0719 & 0.94359 & 4.593 & 0.208 & -3.784 & 0.000 \\
\hline
\end{tabular}

With the analysis of the results presented in the above table (Table 9) we have determined in the overall level of art creative development there is a statistically significant difference $(\mathrm{P}=0.000)$ between the genders. The indicated difference between the genders is in favour of girls; as we find below, however, this is not the case in some other factors of formational development. With the reading of the result we can answer the question (RQ 2 ). We have found there are differences in the overall level of formational development, namely that girls have proved to perform better. The reason for this could lead to the fact that in this period of age girls are more obedient and better manageable than boys, which affects the result of work in visual arts. As concerning the differences in relation to gender for each individual factor we have already found differences in the level of creative development; in tables we will further on also provide an in-depth statistical analysis and interpret the results for this level.

Table 10. Outcomes of the $t$-test and F-test of results in relation to the gender of pupils in propagating elements of art.

\begin{tabular}{|c|c|c|c|c|c|c|c|}
\hline \multirow{2}{*}{$\begin{array}{c}\text { Propagation of elements } \\
\text { of art: }\end{array}$} & \multirow{2}{*}{ G } & \multirow{2}{*}{$\bar{x}$} & \multirow{2}{*}{$\mathrm{s}$} & \multicolumn{2}{|c|}{ F test } & \multicolumn{2}{|c|}{ t-test } \\
\hline & & & & $\mathrm{F}$ & $\mathrm{P}$ & $\mathrm{t}$ & $\mathrm{P}$ \\
\hline \multirow{2}{*}{ line } & M & 2.2537 & 0.92286 & \multirow{2}{*}{0.983} & \multirow{2}{*}{0.322} & \multirow{2}{*}{-2.242} & \multirow{2}{*}{0.026} \\
\hline & $\mathrm{F}$ & 2.5071 & 0.85371 & & & & \\
\hline \multirow{2}{*}{ forms } & M & 2.2116 & 0.86132 & \multirow{2}{*}{0.854} & \multirow{2}{*}{0.356} & \multirow{2}{*}{-1.901} & \multirow{2}{*}{0.058} \\
\hline & $\mathrm{F}$ & 2.4087 & 0.76765 & & & & \\
\hline \multirow{2}{*}{ value } & M & 1.1628 & 0.30031 & \multirow{2}{*}{52.81} & \multirow{2}{*}{0.000} & \multirow{2}{*}{-3.974} & \multirow{2}{*}{0.000} \\
\hline & $\mathrm{F}$ & 1.3357 & 0.37746 & & & & \\
\hline \multirow{2}{*}{ textures } & M & 1.9537 & 0.90222 & \multirow{2}{*}{0.018} & \multirow{2}{*}{0.894} & \multirow{2}{*}{-2.283} & \multirow{2}{*}{0.023} \\
\hline & $\mathrm{F}$ & 2.2119 & 0.87541 & & & & \\
\hline
\end{tabular}

With the results (Table 10) we have found in the factor propagation of elements of art differences occur between the genders. In the propagation of line a statistically significant difference $(\mathrm{P}=0.026)$ shows in favour of girls. Also in the propagation of values we perceived a statistically significant difference $(\mathrm{P}=0.000)$, again in favour of girls, and also in the propagation of texture there is a statistically significant difference $(\mathrm{P}=0.023)$ in favour of girls. In the propa- 
gation of forms, however, a tendency of difference $(\mathrm{P}=0.058)$ has been detected, again in favour of girls. With these results we can answer the question (RQ $2_{\mathrm{S} 1}$ ). Statistically significant differences thus occur in the propagation of line, in the propagation of values, and in the propagation of texture where girls perform better than boys. Furthermore, there is a tendency of difference in the propagation of forms, which also is in favour of girls. The acquired results indicate girls select and build forms, create lines and textures more consciously than boys, as by their very nature they are more inclined towards embellishing things and adding to them, which is also clearly reflected in their drawings.

Table 11. Outcomes of the $t$-test and F-test of results in relation to the gender of pupils in relations between elements of art.

\begin{tabular}{|c|c|c|c|c|c|c|c|}
\hline \multirow{2}{*}{$\begin{array}{l}\text { Relations between } \\
\text { elements of art }\end{array}$} & \multirow{2}{*}{ Gender } & \multirow{2}{*}{$\bar{T}$} & \multirow{2}{*}{$\mathrm{S}$} & \multicolumn{2}{|c|}{$\mathrm{F}$ test } & \multicolumn{2}{|c|}{ t-test } \\
\hline & & & & $\mathrm{F}$ & $P$ & $\mathrm{t}$ & $P$ \\
\hline \multirow{2}{*}{$\begin{array}{l}\text { Use of rhythms to } \\
\text { achieve space }\end{array}$} & M & 1.4570 & 0.80289 & \multirow{2}{*}{7.919} & \multirow{2}{*}{0.005} & \multirow{2}{*}{-4.932} & \multirow{2}{*}{0.000} \\
\hline & $\mathrm{F}$ & 2.0349 & 1.02069 & & & & \\
\hline \multirow{2}{*}{$\begin{array}{l}\text { Use of direction to } \\
\text { achieve space }\end{array}$} & $\mathrm{M}$ & 1.3835 & 0.73022 & \multirow{2}{*}{10.588} & \multirow{2}{*}{0.001} & \multirow{2}{*}{-4.648} & \multirow{2}{*}{0.000} \\
\hline & $\mathrm{F}$ & 1.8841 & 0.94432 & & & & \\
\hline \multirow{2}{*}{ Size and proportions } & $M$ & 2.0793 & 1.04999 & \multirow{2}{*}{5.664} & \multirow{2}{*}{0.018} & \multirow{2}{*}{-3.359} & \multirow{2}{*}{0.001} \\
\hline & $\mathrm{F}$ & 2.5667 & 1.21984 & & & & \\
\hline
\end{tabular}

We have found there is a statistically significant difference in the relations between the elements of art (Table 11), namely in the use of rhythms for achieving space $(\mathrm{P}=0.000)$, size and proportions $(\mathrm{P}=0.000)$ and also in the use of direction for achieving space $(\mathrm{P}=0.000)$. The statistically significant difference was determined with the use of the t-test. Each of the three results is in favour of girls. We can answer the question (RQ $2_{\mathrm{S} 2}$ ). We have found, namely, difference occurs between the genders; i.e. the results have indicated girls perform better than boys. The result is probably influenced by the characteristic of girls who are considered to be more precise and consistent than boys, which in turn is expressed in more coherent proportions, in conscious routing of the line to display space and elsewhere in the drawing.

Table 12. Outcomes of the t-test and F-test of results in relation to the gender of pupils in composition.

\begin{tabular}{|c|c|c|c|c|c|c|c|}
\hline \multirow{2}{*}{ Composition } & \multirow{2}{*}{$\begin{array}{c}\text { Gen- } \\
\text { der }\end{array}$} & \multirow{2}{*}{$\bar{x}$} & \multirow{2}{*}{$\mathrm{s}$} & \multicolumn{2}{|c|}{$F$ test } & \multicolumn{2}{|c|}{$\mathrm{t}$-test } \\
\hline & & & & $\mathrm{F}$ & $\mathrm{P}$ & $\mathrm{t}$ & $\mathrm{P}$ \\
\hline \multirow{2}{*}{ Formal composition } & $\mathrm{M}$ & 2.5314 & 1.24385 & \multirow{2}{*}{0.000} & \multirow{2}{*}{0.983} & \multirow{2}{*}{-1.170} & \multirow{2}{*}{0.243} \\
\hline & $\mathrm{F}$ & 2.7230 & 1.32594 & & & & \\
\hline \multirow{2}{*}{$\begin{array}{l}\text { Suggestiveness of } \\
\text { artistic expression }\end{array}$} & M & 2.3264 & 0.98926 & \multirow{2}{*}{0.159} & \multirow{2}{*}{0.691} & \multirow{2}{*}{-1.272} & \multirow{2}{*}{0.205} \\
\hline & $\mathrm{F}$ & 2.4889 & 1.01636 & & & & \\
\hline
\end{tabular}


Results of the investigation with t-test (Table 12) do not indicate statistically significant differences between the genders in composition, either in the formulation of composition ( $\mathrm{P}=0.243)$ or in the suggestiveness of artistic expression $(\mathrm{P}=0.205)$. Given the findings, we can answer the question ( $\left.R Q 2_{S 3}\right)$. There are thus no differences between the genders, which confirms, both boys and girls strive for consistency of composition in artworks and for suggestiveness of artistic expression.

\section{Conclusions}

»Modern higher education art pedagogy is based on developing students' productive artistic abilities-creative skills - and their receptive abilities. ${ }^{17}$ In artistic-creative level and in the first factor sensitivity for artistic problems girls showed greater sensibility, which was reflected in the results of the research, while in the recognition of artistic problems on the motif we detected no differences between the genders. The results in the factors mental elaboration and aesthetic organisation of expression were in favour of girls, as they were able to reconcile the idea and the material and to observe the rules of formation better than boys.

These results also point to the ability of forward planning, as evidenced in their artworks, which are organised better than those produced by boys. In flexible adaptation to the means of expression a tendency of difference showed in favour of girls concerning the use of felt-tip pen, while in discovering new ways no differences between the genders were discovered. In finding different and unusual solutions of artistic problems no differences were expressed between the genders, and neither in the next factor motor dexterity in the realisation of the idea.

This points to adaptation to the artistic technique of drawing with felt-tip pen and to motor dexterity that allowed them various precise and challenging moves with the pen, in which neither boys nor girls outperformed the others. In the factor artistic originality no statistically significant differences between the genders were detected; girls did, however, put a larger number of unexpected, original, individual, and unusual solutions into their drawings than boys, likewise they performed better than boys in perceiving the elements of artistic structure and in transforming them. In the overall level of artistic-formational the results showed girls are better than boys, which could be a consequence of the fact in this age period girls are more obedient and more easily guided than boys.

\footnotetext{
${ }^{17}$ Matjaž DUH, Developing Art Appreciation in Students of Education from Different European
} Countries, The New Educational Review, 45 (2016) 3, 112-123, 112. 
This showed in the creation of different forms and textures, where a tendency of difference between the genders appeared that was biased toward girls. Meanwhile, in the creation of lines there were no differences between the genders; it seems in both genders creation of lines of all kinds of lines is present. Difference appeared in the creation of brightness tones or in the propagation of values, although the technique of drawing with felt-tip pen does not allow this very much. It proved, nevertheless, girls strive more than boys to represent various brightness tones. They are also better in bringing rhythm into lines and forms to achieve space and they also more consciously than boys guide lines into the direction for perception and presentation of space on the plane. To size and proportions by girl cause fewer problems than to boys, they bring more coherent proportions between the elements of art into their drawings than boys. In spite of better command of size and proportions no differences were perceived in composition. In assembling the elements of art into a balanced whole both achieved approximately the same results. We can sum up in both levels certain differences appear in relation to some factors and criteria, they prevail, however, in the level of artistic-formational development.

This indicates according to statistical results girls are more progressive than boys. Given the results, the performed research provides insight into the state of artistic abilities of both genders, for comparison of results it can serve further research, and it provides information to educational professionals and everyone interested in the monitoring of artistic abilities of children. 


\section{Jerneja Herzog* \\ Kreativne sposobnosti učenica $i$ učenika sedmoga razreda u slovenskim osnovnim školama \\ Sažetak}

U radu su izneseni rezultati empirijskoga istraživanja u kojem se pratilo kreativne sposobnosti učenica i učenika sedmoga razreda u slovenskim osnovnim školama. Pratile su se razine umjetničko-kreativnoga i umjetničkooblikovnog razvitka. U istraživanju je sudjelovalo 247 učenica i učenika, a uzete su u obzir i razlike u kreativnim sposobnosti u odnosu na spol. Rezultati istraživanja pokazali su da učenice dominiraju u umjetničko-oblikovnom razvoju nad učenicima, a u umjetničko-kreativnom razvitku nije bilo statistički značajnih razlika.

Ključne riječi: umjetnički kreativni razvoj učenica i učenika, umjetnički oblikovni razvoj učenica i učenika, kreativnost, nastava umjetnosti.

(na engl. i hrv. prev. Mirko Zorman)

\footnotetext{
* Doc. dr. sc. Jerneja Herzog, Odsjek za likovnu umjetnost Pedagoškoga fakulteta Sveučilišta u Mariboru; Adresa: Koroška cesta 160, SI-2000 Maribor, Slovenija; E-mail: jerneja.herzog@ um.si.
} 